\title{
A mantle metasomatic injection event linked to Permo- Carboniferous lamprophyre magmatism and associated rare metal ore deposition (Sn-W-Mo-Li-Sc-In / Ag(-Au)-In-base metal) in the eastern European Variscides
}

\author{
Thomas Seifert ${ }^{1}$ \\ ${ }^{1}$ TU Bergakademie Freiberg, Freiberg, Germany, thomas.seifert@mineral.tu-freiberg.de
}

\section{Introduction}

Lamprophyres which are of mantle origin in subduction zones and continental rift settings are reported as components of bimodal dike suites in a number of hydrothermal Au-polymetallic, $\mathrm{Au}-\mathrm{Cu}, \mathrm{Ag}$-base metal, $\mathrm{Ag}(-\mathrm{Au})-\mathrm{Sb}, \mathrm{Sb}-\mathrm{Hg}$ and fluorite deposits (Rock 1991; Seifert 2007, 2010; Geißler and Seifert 2009). Significant is the association of Sn-W, Sn-sulfide, Sn-In-polymetallic and Ag(-Au)-In-Sb-base metal deposits with Paleozoic and Mesozoic magmatism in the Erzgebirge, Central Asia, and Yakutia which includes granitoids and abundant mafic dikes (Seifert 2008; Seifert et al. 2011, Štemprok and Seifert 2011).

The traditional model for the genesis of late-Variscan deposition of Sn-W-Mo ores in the eastern Variscides favored a crustal-derived, syn- to late-collision granite magmatism (Tischendorf 1986). An alternative model suggests a mantle-related magmatic pulses and associated high-temperature and rare metal-enriched fluids as a source of late-Variscan Sn-, In-, and Ag-polymetallic mineralization in the Erzgebirge-Vogtland metallogenic province (Seifert 2008, 2015). Calc-alkaline lamprophyres (CAL) of the present study crop out in rock quarries, outcrops at roads and railway lines, and often in underground mines of old mining districts ( $15^{\text {th }}$ to $20^{\text {th }}$ century).

\section{Geology of late-Variscan lamprophyric intrusions}

The calc-alkaline lamprophyric dikes and sills (CAL) in the Erzgebirge-Vogtland region are typically $0.5-5 \mathrm{~m}$ wide, rarely exceeding $30 \mathrm{~m}$. The most CAL occur in areas of crosscutting deep fault zones and lineaments which also act as conduits for post-collisional, F-enriched granitic/rhyolitic intrusions and host post-magmatic Sn-W-Mo-Li-Sc-In, Sn-In-base metal, Ag(-Au)-Sb-base metal, and U deposits (e.g., crosscutting area of the NW-SE Gera-Jáchymov fault zone and the NE-SW Saxonian Lineament; cf. Seifert 2008). CAL took place in the Erzgebirge/Krušné hory-Fichtelgebirge anticlinorium (cf. Seifert 2008 and references therein) and Fichtelgebirge/Smčiny pluton (Gümbel 1874) in different host rocks (ortho- and paragneisses, mica-schists, phyllites, meta-basalts, meta-carbonates, meta-black shales and late-Variscan granites/rhyolites) in NW-SE, NE-SW/NNE-SSW, and ENE-WSW trending dikes.

\section{Petrology and relatively age relationships}

The calc-alkaline lamprophyric intrusions in the Erzgebirge are divided by Seifert (1997, 2008, this study) using criteria of relatively age relationships to different late-Variscan granite intrusions and associated aplites, rhyolitic and lamprophyric dikes, and late-Variscan rare metal mineralization stages as well as petrographic and geochemically criteria (LD1 - LD3, Fig. 1):

(1) The late-collisional LD1-type lamprophyres (330 Ma) are intruded by late-collisional granites (e.g., Ehrenfriedersdorf Sn-W district, Schlema-Schneeberg U-Ag district) and are characterized by transitional type kersantitic/spessartitic dike intrusions. They predate all Permo-Carboniferous mineralization stages in the Erzgebirge-Vogtland area and are possibly unrelated to late-Variscan ore deposition processes. LD1 show similarities to lampropyhric dikes in the Elbe Zone with K-Ar ages of c. $330 \mathrm{Ma}$ (Kurze et al. 1998).

(2) LD2-type lamprophyres (320-300 Ma) postdate the late-collisonal ("Eibenstock type") granite intrusions and occur widely in the Sn-W-U district Gottesberg-Mühlleithen, U-Ag district SchlemaSchneeberg, Sn-In-Ag-U districts Marienberg-Pobershau and Annaberg, and probably in the Ag-In-Sn- 
base metal district Freiberg. LD2 are dominated by mica-minette dike intrusions with strike lengths up to $7 \mathrm{~km}$ and a thickness up to $10 \mathrm{~m}$. They are crosscutt by Sn-polymetallic, $\mathrm{Ag}(-\mathrm{Au})-\mathrm{In}$-Sb-base metal, $\mathrm{U}$, fluorite-barite, and Bi-Co-Ni-As-Ag(-U) mineralization.

(3) LD3-type lampropyhres (310-300? Ma) are identified in the Pobershau Sn-W-Ag ore field and represented by feldspar-phyric kersantitic lamprophyres. LD3 in the Pobershau ore field show post-Sn mineralization age and are crosscutt by barite-Bi-Co-Ni-Ag veins

The texture of the LD2-type lamprophyres is partly richly porphyric (phlogopite), with a fine-grained grey-black groundmass. In some LD2-samples from the Marienberg and Freiberg districts a F-enriched phlogopite is the dominated mineral. LD2 in the Tannenberg-Mühlleiten district show low phyric textures and nearly glassy groundmass. Typically for LD1-type lamprophyres are mica-, amphibole-, and feldspar-microphyric textures. The contact between the lamprophyre dikes and host rocks is always sharp and c. 2-20 mm chilled margins are often present. The most lamprophyres are characterized by early-magmatic (micro)phenocrysts of $\mathrm{Mg}$-biotites/phlogopites with typical zonation and/or amphibole (micro)phenocrysts. They mostly contain clinopyroxene (diopside, augite) and, locally, olivine. Olivine may enclose Cr-spinel, but is often pseudomorphosed of secondary carbonate, chlorite, amphibole, and talc. Mica-minettes (LD2) have higher modal abundances of alkali feldspar, phlogopite and apatite than LD1 and LD3. This characterization is similar to mafic volcanics of the Sub-Erzgebirge basin (MVSEB). Fluor-apatite is the most common accessory mineral in LD2 and MVSEB.

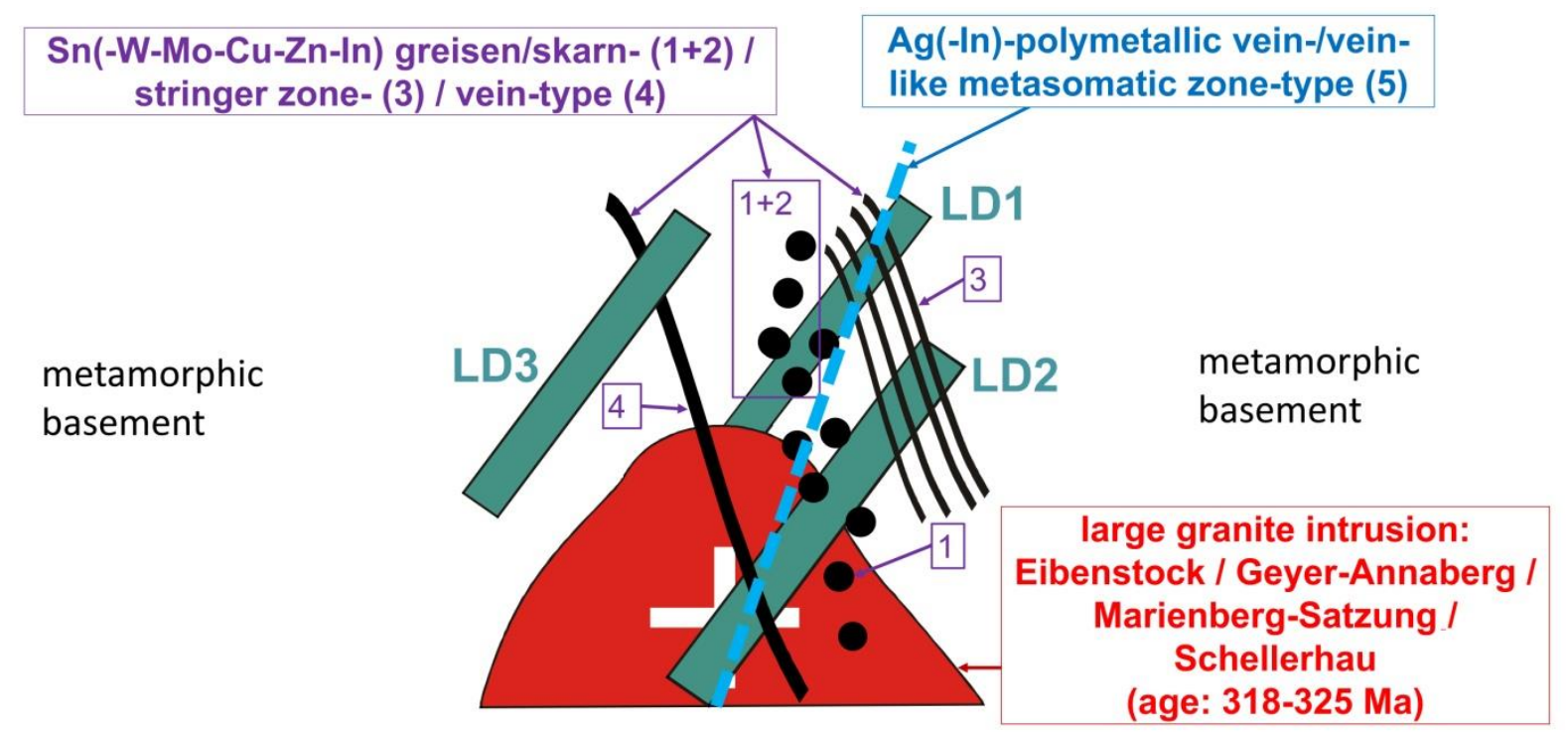

Figure 1: Relatively age relationships of late-Variscan large granite intrusions (western Erzgebirge: Eibenstock; central Erzgebirge: Ehrenfriedersdorf-Geyer-Annaberg / Marienberg-Pobershau-Satzung; eastern Erzgebirge: Schellerhau) and lamprophyric dike intrusions (LD1, LD2, LD3) and rare metal mineralization (1 to 5) in the Erzgebirge-Vogtland region (modified from Seifert 2010, 2015).

\section{Geochemistry}

Geochemically LD2 (phlogopite-phyric minette and transitional type kersantite/minette) show a typically ultrapotassic composition similar to the majority of MVSEB. The high concentration of LILE (up to 8.74 wt.\% $\mathrm{K}_{2} \mathrm{O}, 1,100 \mathrm{ppm} \mathrm{Rb}, 100 \mathrm{ppm} \mathrm{Cs}, 5,020 \mathrm{ppm} \mathrm{Ba}, 2,030 \mathrm{ppm} \mathrm{Sr}$ ) and HFSE (up to 3.7 wt.\% $\mathrm{TiO}_{2}, 1.3$ wt. $\% \mathrm{P}_{2} \mathrm{O}_{5}, 30$ ppm Sc, 1,070 ppm Zr, 35 ppm Hf, 115 ppm Nb, 95 ppm Th, 75 ppm Y, $700 \mathrm{ppm}$ LREE) and the enriched radiogenic isotope composition of LD2 and MVSEB ${ }^{87}{ }^{8 r} /{ }^{86} \mathrm{Sr}_{\mathrm{i}}=$ 0.70401 to $0.71038 ; \varepsilon \mathrm{Nd}_{\mathrm{i}}=-6.4$ to -0.2$)$ indicate melting of a metasomatically enriched mantle. High concentrations of LILE and HFSE, and the 'primitive' bulk geochemistry indicated by high mg\# (76 88) and $\mathrm{Cr}$ (up to $890 \mathrm{ppm}$ ), $\mathrm{Ni}$ (up to $470 \mathrm{ppm}$ ), and Co contents (up to $55 \mathrm{ppm}$ ) exclude significant crustal contamination as the cause of their enrichment. High volatile contents $\left(\mathrm{CO}_{2}\right.$ up to $7.3 \mathrm{wt} . \%$, $\mathrm{H}_{2} \mathrm{O}^{+}$up to 7.92 wt.\%, F up to $4,600 \mathrm{ppm}, \mathrm{Cl}$ up to $1,700 \mathrm{ppm}, \mathrm{S}$ up to $3,160 \mathrm{ppm}, \mathrm{P}_{2} \mathrm{O}_{5}$ up to 1.33 
wt.\%) in whole rock samples and high $\mathrm{H}_{2} \mathrm{O}^{+}, \mathrm{F}$ and $\mathrm{Cl}$ contents of early magmatic phlogopites and apatites are typical for post-collisional lamprophyres in the Erzgebirge (especially LD2) and shoshonitic/ultrapotassic mafic volcanics in the Sub-Erzgebirge basin.

A carbonate-rich mica-lamprophyre from the nearby Berga anticlinorium (drill hole 4215-76 of SDAG Wismut) is characterized by extremely high $\mathrm{CO}_{2}(12.20 \mathrm{wt} . \%), \mathrm{P}_{2} \mathrm{O}_{5}(2.28 \mathrm{wt} . \%), \mathrm{F}(3,200 \mathrm{ppm}), \mathrm{Sr}$ (2,940 ppm), Th (135 ppm), and $\sum \operatorname{REE}(1,400 \mathrm{ppm})$ contents (Seifert 2008) and show in the $\mathrm{Sm}-\mathrm{Ce} / \mathrm{Yb}$ and Sm-La/Yb diagram (Rock 1991; Mitchell and Bergmann 1991) a clear tendency to the lamproite field.

\section{Bimodal post-collisional magmatism and metallogenic importance for rare metal mineralization}

The bimodal lamprophyre-rhyolite assemblage in the Erzgebirge/Sub-Erzgebirge basin area was formed during intracontinental rifting in a 'Fast Extension' setting by melting of a metasomatic enriched mantle source. The emplacement of fluid-enriched lamprophyric and rhyolitic intrusions at the same time is possibly associated with decompression melting of updoming asthenosphere and a mantle plume with a peak magmatic activity from 300 to $280 \mathrm{Ma}$ (cf. Seifert 2009). The metallogenetic importance of postcollisional lamprophyres (especially type LD2) and MVSEB is indicated by their high volatile concentrations and relationships to post-collisional high-F granitic intrusions and high-F (partly high$\mathrm{Sn}$ ) subalkaline rhyolites/rhyolitic ignimbrites and late-Variscan rare metal ore deposition.

\section{References}

Geißler L, Seifert T (2009) Geology, Mineralogy and Geochemistry of Gold-bearing Polymetallic Sulfide-Quartz Veins and Associated Intrusions in the French Gulch-Deadwood District, California. Freiberger Forschungshefte C 533

Gümbel CW (1874) Die paläolithischen Eruptivgesteine des Fichtelgebirges. Franz, München

Kurze M, Seifert T, Weber H, Henjes-Kunst F (1998) Petrographie, Geochemie und Altersstellung der Lamprophyr-Gänge des Elbtalschiefergebirges (Sachsen). Z. Geol. Wiss. 26: 193-202

Mitchell RH, Bergman SC (1991) Petrology of lamproites. Plenum Press, New York, London

Rock NMS (1991) Lamprophyres. Blackie, Van Nostrand Reinhold, Glasgow, New York

Seifert T (1997) Mantle metasomatism and associated late Variscan Sn and base metal mineralization in the Erzgebirge (Germany). In: Hatton CJ (ed) Plumes, Plates and Mineralisation, proceedings volume, University of Pretoria, pp 89-90

Seifert T (2007) Metallogenetische Bedeutung von Kalkalkali-(CA-)Lamprophyren - Beitrag zur Genese und Exploration von Sn-W-Mo-, Ag-Polymetall- und U-Lagerstätten am NW-Rand des Böhmischen Massivs (DE, CZ). Habilitation, TU Bergakademie Freiberg

Seifert T (2008) Metallogeny and Petrogenesis of Lamprophyres in the Mid-European Variscides. IOS Press BV, Amsterdam

Seifert T (2009) Late-Variscan polymetallic ore deposits in central Europe and their relationships to large igneous provinces (LIP) and mantle plume magmatism. Large Igneous Provinces Commission of IAVCEI. http://largeigneousprovinces.org/09oct. Accessed October 2009

Seifert T (2010) Contributions to the metallogenetic importance of lamprophyres - examples from polymetallic Au-, Sn-W-Mo-Li-In-, As-Zn-Sn-Cu-In-Pb-Ag- / Ag-Sb-, and U-ore clusters. MINERALOGIA - SPECIAL PAPERS 37: 55-58

Seifert T (2015) Paragenesis, geochemistry and age of late-Variscan Sn, In and Ag mineralization in the Marienberg district and its relationship to mafic and acidic magmatic events, Erzgebirge. In: André-Meyer AS et al (ed) 13th SGA Biennial Meeting 2015, France, Proceedings, Volume 2, pp 843-846

Seifert T, Pavlova GG, Borisenko AS (2011) Types of Ag-polymetallic/Ag-Sb vein-type mineralization in the European Variscides, Yakutia, Altai, Tien Shan, and Pamir. In: Geology, Tectonics and Minerogeny of Central Asia, VSEGEI, St. Petersburg, Russia, conference CD

Štemprok M, Seifert T (2011) An overview of the association between lamprophyric intrusions and rare-metal mineralization. MINERALOGIA 42: 121-162

Tischendorf G (1986) Variscan ensialic magmatism and metallogenesis in the Ore Mountains Modelling of the process. Chemie der Erde 45: 75-104 